\title{
A new method of resolving annual precipitation for the past millennia from Tibetan ice cores
}

\author{
Wangbin Zhang ${ }^{1}$, Shugui Hou ${ }^{1,2,3}$, Shuang-Ye Wu ${ }^{4}$, Hongxi Pang ${ }^{1,2}$, Sharon B. \\ 5 Sneed $^{5}$, Elena V. Korotkikh ${ }^{5}$, Paul A. Mayewski ${ }^{5}$, Theo M. Jenk ${ }^{6,7}$, and Margit \\ Schwikowski ${ }^{6,7}$ \\ ${ }^{1}$ School of Geography and Ocean Science, Nanjing University, Nanjing 210023, China. \\ ${ }^{2}$ Collaborative Innovation Center of Climate Change, Jiangsu Province, Nanjing, China. \\ ${ }^{3}$ School of Oceanography, Shanghai Jiao Tong University, Shanghai 200240, China. \\ ${ }^{4}$ Department of Geology, University of Dayton, Dayton, OH 45469, USA. \\ ${ }^{5}$ Climate Change Institute, University of Maine, Orono, ME 04469, USA. \\ ${ }^{6}$ Laboratory of Environmental Chemistry, Paul Scherrer Institute, CH-5232 Villigen PSI, Switzerland. \\ ${ }^{7}$ Oeschger Centre for Climate Change Research, University of Bern, Sidlerstrasse 5, CH-3012 Bern, \\ 15 \\ Switzerland.
}

Correspondence to: Shugui Hou (shugui@nju.edu.cn; shuguihou@sjtu.edu.cn)

\begin{abstract}
Net accumulation records derived from ice cores provide the most direct measurement of past precipitation. However, quantitative reconstruction of accumulation for past millennia remains challenging due to the difficulty in identifying annual layers in the deeper sections of ice cores. In this study, we propose a new method to quantify annual accumulation from ice cores for past millennia, using as an example an ice core drilled at the Chongce ice cap in the northwestern Tibetan Plateau (TP). First, we used the Laser Ablation Inductively Coupled Plasma Mass Spectrometry (LA-ICP-MS) technology to develop an ultra-high-resolution trace element records in three sections of the ice core and identified annual layers in each section based on seasonality of these elements. Second, based on nine ${ }^{14} \mathrm{C}$ ages determined for this ice core, we applied a two-parameter flow model to established the thinning parameter of this ice core. Finally, we converted the thickness of annual layers in the three sample sections to past accumulation rates based on the thinning parameter derived from the ice-flow model. Our results show that the mean annual accumulation rate for the three sample sections are $102 \mathrm{~mm} / \mathrm{year}$ (2511-2541 a B.P.), 76 mm/year (1682-1697 a B.P.) and 84 mm/year (781-789 a B.P.). For comparison,
\end{abstract}




\section{Introduction}

Precipitation, including both snowfall and rainfall, is a crucial component of the Earth's energy and water cycles, and is the most important and variable parameter associated with atmospheric circulation in weather and climate studies (Kidd and Huffman, 2011). Accurate and reliable knowledge of precipitation is of paramount importance not only for the study of water resource management, but also for understanding and monitoring the Earth's climate change (Kidd and Huffman, 2011; Sun et al., 2018). The earliest systematic instrumental observations of precipitation (i.e., rain gauges) began in the eighteenth century in Europe, but they were not put in place until much later in other parts of the world (Christiansen and Ljungqvist, 2017). Our knowledge of precipitation in earlier times therefore relies on precipitation-sensitive proxy records from different types of biological and geological archives, e.g., tree rings, stalagmite, terrestrial and marine sediment, and ice cores (Cai et al., 2012; Kaspari et al., 2008; Thompson et al., 2006; Xu et al., 2019; Yang et al., 2014).

Net accumulation recorded in ice cores provides the most direct measurement for past precipitation, as glacier are formed by accumulating annual layers of snow (Paterson and Waddington, 1984). However, in order to derive accurate net accumulation records, sampling resolution must be high enough to obtain reliable annual-layer thickness information. In addition, the nonlinear thinning of annual layers caused by ice flow must be suitably constrained (Bolzan, 1985; Henderson et al., 2006; Roberts et al., 2015). The most common approach is to obtain annual-layer thickness based on the seasonal cycles of ice core parameters such as stable isotope ratio of oxygen in the water $\left(\delta^{18} \mathrm{O}\right)$, the concentration of major ions (e.g. $\mathrm{Ca}^{2+}, \mathrm{Mg}^{2+}, \mathrm{NH}_{4}^{+}, \mathrm{SO}_{4}^{2-}$ ), and the presence of melt layers (Thompson et al., 2018). The thinning parameter of ice cores is usually derived from an ice flow model constrained by the ages of absolute chronological markers, e.g., peak of beta and/or tritium activity from thermonuclear bomb testing in the second half of the $20^{\text {th }}$ century, well-defined aerosol layers and/or tephra from large volcanic eruptions, and radioactive dating method based on ${ }^{210} \mathrm{~Pb}$ activity decay (Uglietti et al., 2016; Zhang et al., 2015). Using these conventional methods, a great number of accumulation records were developed from ice cores over the past decades, covering decades to centuries (Alley et al., 1993; Dahl-Jensen et al., 1993; Hardy et al., 2003; Henderson et al., 2006; Hou et al., 2002; Kaspari et al., 2008; Yao et al., 2008). However, it remains challenging to develop annually resolved accumulation records covering longer (e.g. 
chronologies in the deeper part of ice cores due to rapid thinning (Roberts et al., 2015; Winstrup et al., 2012). During the past two decades, several effective methods, e.g., the continuous flow analysis (CFA) technology and the Laser Ablation Inductively Coupled Plasma Mass Spectrometry (LA-ICP-MS) technology, were developed to measure the chemicals preserved in ice cores with millimeter to submillimeter sampling resolution. The resulting ultra-high resolution records could reveal seasonal signals of chemical constituents in ice cores, and were increasingly used to accurately discern annual layers of ice cores from Antarctica, Greenland, and the Alps (Bohleber et al., 2018; Clifford et al., 2019; Haines et al., 2016; Massam et al., 2017; More et al., 2017; Winstrup et al., 2019). The remaining challenge for reconstructing long-term accumulation records thus lies in establishing accurate thinning parameters, and this is largely dependent on the reliable dating of ice cores, particularly at deeper sections. Recently, a novel method was developed to extract water-insoluble organic carbon (WIOC) particles at microgram level from carbonaceous aerosol embedded in the glacier ice for accelerator mass spectrometry (AMS) ${ }^{14} \mathrm{C}$ dating (Uglietti et al., 2016). Carbonaceous aerosols are constantly transported to high-altitude glaciers, where they are deposited and eventually incorporated into the glacier ice. Consequently, carbonaceous aerosols in ice cores can provide reliable dating at any given depth when the samples contain sufficient WIOC (>10 $\mu \mathrm{g}$ ). These dates can then be used to constrain an ice flow model to estimate the mean accumulation rate and thinning parameter of ice cores.

In this study, we propose a new method to establish annual accumulation record of past millennia, taking three sections from an ice core drilled at the Chongce ice cap in the northwestern Tibetan Plateau (TP) as an example (Fig. S1). First, we measured the concentration of aluminum (Al), calcium (Ca), iron $(\mathrm{Fe})$, sodium $(\mathrm{Na})$, magnesium $(\mathrm{Mg})$, copper $(\mathrm{Cu})$, and lead $(\mathrm{Pb})$ from the three sections of the Chongce ice core. Based on the seasonal cycles of these elements, we identified annual layers in the ice core and measured their thickness. Second, we derived the thinning parameter and the mean accumulation rate of the entire Chongce ice core using a two-parameter steady state flow model constrained by the ${ }^{14} \mathrm{C}$ ages and the ages of other reference layers (e.g., $\beta$ activity peak). Based on the results, we calculated the modeled annual layer thickness for mean accumulation at different depths. Finally, we derived the actual accumulation for each annual layer within the three sample sections as the product of the ratio of the observed to modeled annual layer thickness and the average annual accumulation of this ice core. We verified the reliability of this method by comparing our results with other reconstructed and modeled precipitation series for the TP. 
https://doi.org/10.5194/tc-2021-115

Preprint. Discussion started: 26 May 2021

(c) Author(s) 2021. CC BY 4.0 License.

\section{Materials and methods}

\subsection{Retrieval and analysis of the Chongce ice core}

The Chongce ice cap is located in the western Kunlun Mountains on the northwestern TP (Fig. S1), covering an area of $163.06 \mathrm{~km}^{2}$ with a volume of $38.16 \mathrm{~km}^{3}$ (Shi, 2008). The ice cap faces south with a mean equilibrium line altitude of $5900 \mathrm{~m}$ above sea level (a.s.l.) (Fig. S1). Climate of the Chongce ice cap and its vicinity is largely controlled by the strength of the mid-tropospheric westerlies (Fig. S2). Based on the High Asia Refined analysis (HAR) data (available at: https://www.klima.tuberlin.de/)(Maussion et al., 2014), precipitation over the Chongce ice cap is highly seasonal. Summertime precipitation accounts for $\sim 28 \%$ of the annual total, whereas the amount from December to May accounts for $\sim 59 \%$ (Fig. S3 and S4). Autumn (September to November) has the lowest amount of precipitation.

In October 2012, we retrieved two ice cores to bedrock with lengths of $134.03 \mathrm{~m}$ (Core 1 , $35^{\circ} 14^{\prime} 5.77^{\prime \prime} \mathrm{N}, 81^{\circ} 7^{\prime} 15.34^{\prime \prime} \mathrm{E}, 6010 \mathrm{~m}$ a.s.1.) and $135.81 \mathrm{~m}\left(\right.$ Core $2,35^{\circ} 14^{\prime} 6.11^{\prime \prime} \mathrm{N}, 81^{\circ} 6^{\prime} 50.62^{\prime \prime} \mathrm{E}, 6010 \mathrm{~m}$ a.s.1.) and a shallow ice core with a length of $58.82 \mathrm{~m}\left(\right.$ Core $3,35^{\circ} 14^{\prime} 5.69^{\prime \prime} \mathrm{N}, 81^{\circ} 6^{\prime} 51.71^{\prime \prime} \mathrm{E}, 6010 \mathrm{~m}$ a.s.1.) from the Chongce ice cap with an electromechanical drill. The distance between the drilling sites of Core 2 and Core 3 is $~ 2$ meters. In October 2013, two more ice cores to bedrock were recovered from the Guozha glacier on the same ice cap with lengths of $216.61 \mathrm{~m}\left(\right.$ Core $4,35^{\circ} 14^{\prime} 56.58^{\prime \prime} \mathrm{N}, 81^{\circ} 5^{\prime} 27.70^{\prime \prime} \mathrm{E}$, $6105 \mathrm{~m}$ a.s.1.) and $208.63 \mathrm{~m}$ (Core 5, 35 ${ }^{\circ} 14^{\prime} 56.00^{\prime \prime} \mathrm{N}, 81^{\circ} 5^{\prime 2} 28.06^{\prime \prime} \mathrm{E}, 6104 \mathrm{~m}$ a.s.1.) (Fig. S1). Borehole temperatures are $-12.8,-12.6$ and $-12.6{ }^{\circ} \mathrm{C}$ at $10 \mathrm{~m}$ depth for Core 1 , Core 2 , and Core 3 , and -8.8 and $8.8{ }^{\circ} \mathrm{C}$ at $130 \mathrm{~m}$ depth for Core 1 and Core 2, respectively (Fig. S5), suggesting that the Chongce ice cap is frozen to the bedrock (Hou et al., 2018). The density profiles of Core 2, Core 3, and Core 4 are shown in Fig. S6. All the ice cores were kept frozen and transported to the cold laboratory $\left(-20^{\circ} \mathrm{C}\right)$ at Nanjing University for further processing.

\subsection{Ultra-high resolution glaciochemical analysis of the Chongce ice core using LA-ICP-MS}

LA-ICP-MS analysis was conducted at the W. M. Keck Laser Ice Core Facility of the Climate

Change Institute, the University of Maine, following procedures presented by Sneed et al. (2015) and Spaulding et al. (2017). The system includes the following components: a Thermo Element 2 ICP-MS (Thermo Fisher Scientific, Bremen, Germany) coupled to a standard New Wave UP-213 laser ablation system (New Wave Research, Fremont, California, USA); and the Sayre CellTM, a cryocell chamber designed to hold $1 \mathrm{~m}$ of ice at a temperature of $-15{ }^{\circ} \mathrm{C}$. The chamber is equipped with a small $\left(\sim 5 \mathrm{~cm}^{3}\right)$ 
open-design ablation chamber for continuous ablation of ice core samples at close to their original length (Spaulding et al., 2017).

We selected three trial sections from Core 2 (Section I, II, and III) for the ultra-high resolution LAICP-MS analysis, as well as the top section of Core 3 (Top Section) for conventional chemical analysis ( $3 \mathrm{~cm}$ sampling resolution) for comparison (An et al., 2016). The depths of these sections are 0-10.030 $\mathrm{m}$ for the Top Section (Core 3), 72.645-73.151 $\mathrm{m}$ for Section I, 107.977-108.389 $\mathrm{m}$ for Section II, and 122.670-123.032 m for Section III (Core 2) (An et al., 2016). Prior to analysis, Section I, II, and III were split axially into two halves using a band saw. One half was stored as an archive. For the remaining half, we first scraped the surface (longitudinal section) with a Lie Nielson stainless-steel blade to remove possible contamination caused by previous sample preparation. The ice sample was then placed in the W.M. Keck Laser Ice Facility Sayre Cell ${ }^{\mathrm{TM}}$ whilst the Argon (Ar) gas flow was purged for two minutes to remove impurities in the system. To save analysis time, the multi-element method of LA-ICP-MS analysis (Spaulding et al. 2017) was used to measure $\mathrm{Na}, \mathrm{Mg}, \mathrm{Cu}$, and $\mathrm{Pb}$ from an ablated line along the surface of the ice core, and Al, Ca, Fe from a parallel line. These two ablated lines were separated by $200 \mu \mathrm{m}$ to prevent any possible overlap. The sampling resolution is $153 \mu \mathrm{m}$ per sample. The unit of LA-

ICP-MS measurements is intensity (counts per second (cps)).

\section{$2.3 \beta$ activity measurements}

Twenty-two samples were collected successively from the top to a depth of $14.805 \mathrm{~m}$ of the Chongce Core 3. Each sample is about $1 \mathrm{~kg}$. The $\beta$ activity was measured using an Alpha-Beta Multidetector (Mini 20, Eurisys Mesures) at the State Key Laboratory of Cryospheric Science, Lanzhou, China. Details about $\beta$ activity measurements can be found in An et al. (2016).

\section{$2.4{ }^{14} \mathrm{C}$ measurements}

The ${ }^{14} \mathrm{C}$ measurements were made at the Paul Scherrer Institut and the University of Bern (LARA laboratory), Switzerland. Nine samples from the Chongce Core 2 were selected for ${ }^{14} \mathrm{C}$ dating (Hou et al., 2018) using a method based on ${ }^{14} \mathrm{C}$ determination in the water-insoluble organic carbon fraction 
The samples were then melted to collect the water-insoluble carbonaceous particles contained in the ice were by filtration. The filters were subsequently combusted at $340^{\circ} \mathrm{C}$ and then $650^{\circ} \mathrm{C}$ to separate organic carbon (OC) from element carbon (EC). The resulting $\mathrm{CO}_{2}$ was measured by the Mini Carbon Dating System (MICADAS) with a gas ion source for ${ }^{14} \mathrm{C}$ analysis. Details about sample preparation and WIOC separation can be found in the previous studies (Uglietti et al., 2016). The overall procedural blanks were estimated using artificial ice blocks of frozen ultra-pure water, which were treated the same way as real ice samples. The average overall procedural blank is $1.34 \pm 0.62 \mu \mathrm{g}$ carbon with a $\mathrm{F}^{14} \mathrm{C}$ of $0.69 \pm 0.13$ (https://c14.arch.ox.ac.uk/) (Bronk Ramsey and Lee, 2013) with the IntCal13 calibration curve (Reimer et al., 2013).

\subsection{Annual-layer identification using the StratiCounter program}

To verify our annual-layer identification, we applied the StratiCounter program to identify annual layers for Section III. This is an automated annual-layer detection method based on the Hidden Markov Model (HMM) algorithms (Winstrup et al., 2012). The code for the StratiCounter program is available at the github repository (http://www.github.com/maiwinstrup/StratiCounter).

\subsection{The TraCE-21ka simulation}

For comparison, we also used data from the "Simulation of Transient Climate Evolution over the Last 21,000 years" (TraCE-21ka) (Collins et al., 2006; Liu et al., 2009). The TraCE-21ka experiment was performed using a state-of-the-art coupled ocean-atmosphere model, the Community Climate Model version3 (CCSM3), forced by realistic variations in insolation, atmospheric greenhouse gases (GHGs), meltwater fluxes and continental ice sheets. The atmospheric resolution is $3.75^{\circ} \times 3.75^{\circ}$ horizontally, with 26 vertical levels. we calculated annual precipitation in the western Kunlun Mountains covering the last three millennia based on outputs from the TraCE-21ka climate simulation (available at: https://www.earthsystemgrid.org). 


\section{Results}

\subsection{Annual-layer identification using multiple chemical species}

Various chemical species obtained from Tibetan ice cores exhibit distinct seasonal cycles (An et al., 2016; Thompson et al., 2018). On the northwestern TP, the $\delta^{18} \mathrm{O}$ values in modern precipitation show distinct seasonal fluctuations with high values in summer and low values in winter (Thompson et al., 2018). In addition, chemical elements (e.g., $\mathrm{Al}, \mathrm{Ca}, \mathrm{Fe}$, and $\mathrm{Mg}$ ) also show marked seasonal cycles with high concentrations in late winter and spring and low concentrations in summer (Thompson et al., 2018).

In this paper, annual layers of the Top Section were identified based on seasonal cycles of $\delta^{18} \mathrm{O}$ values (Fig. 1). The distance between two adjacent low $\delta^{18} \mathrm{O}$ values was defined as the annual layer thickness (An et al., 2016). The result was verified by a reference of $\beta$ activity peak in 1963 A.D. due to thermonuclear bomb testing, and a second $\beta$ activity peak in 1986 A.D. corresponding to the Chernobyl nuclear accident. The derived average annual layer thickness of the Top Section is $168.61 \pm 61.91 \mathrm{~mm}$ (corresponding to $140.76 \pm 48.56 \mathrm{~mm}$ w.e.) (Fig. 1). Annual layers of Section I, II, and III were identified based on seasonal cycles of $\mathrm{Al}, \mathrm{Ca}, \mathrm{Fe}, \mathrm{Mg}$. In these sections, the LA-ICP-MS profile of each element $(\mathrm{Al}, \mathrm{Ca}, \mathrm{Fe}$, and $\mathrm{Mg}$ ) is characterized by the regular occurrence of several distinct peaks grouped together, along with an elevated baseline of each element's concentration (Fig. S7). The groups of peaks are separated by a prolonged section of low element concentrations (Fig. 1 and S7). The grouped peaks are interpreted as independent snow events of elevated element concentrations during the winter/spring (Fig. S7). The periods of low values correspond to snow deposition during the summer (Fig. S7). Annual layer boundaries of Section I, II, and III were defined as the local maxima (maximum in each group of peaks) in the concentration of the four elements (Fig. S7). It is worth nothing that seasonal cycles of these elements are not always synchronous, so the identification of annual layers requires expert judgment. Fig. 1 shows annual layer delineation for each of the three sections. The derived average annual layer thickness for Section I, II, and III is $47.73 \pm 16.98 \mathrm{~mm}$ (corresponding to $38.59 \pm 13.73 \mathrm{~mm}$ w.e.), 19.24 $\pm 3.66 \mathrm{~mm}$ (corresponding to $15.39 \pm 2.93 \mathrm{~mm}$ w.e.), and $11.92 \pm 3.92 \mathrm{~mm}$ (corresponding to $9.53 \pm 3.13$ mm w.e.) respectively.

To verify our layer identification, we applied the StratiCounter program to identify annual layers objectively for Section III (Fig. S8). This is an automated annual-layer detection method based on the 
StratiCounter produced largely comparable results. The average annual layer thickness derived from the StratiCounter counts is $11.15 \pm 4.84 \mathrm{~mm}$ (corresponding to $8.92 \pm 3.87 \mathrm{~mm}$ w.e.), which is about $6.5 \%$ lower than our estimate from the manual layer counting. This confirms the reliability of our manual layer counting. The StratiCounter program could not be applied to Sections I and II due to their short duration.

For consistency, we used results from manual layer counting for further analysis and discussions.

\subsection{Thinning of annual layers due to ice flow}

Glaciers consist of sequences of sedimentary deposits of annual snow in polar and alpine regions (Rapp, 2012). Snow layers sink into the ice mass and are subjected to continuous thinning (Rapp, 2012; Nye, 1963). This occurs initially due to densification, by which the snow is gradually transformed into ice, but later mainly because of flow induced vertical compressive strain. Therefore, the observed thickness of an annual layer reflects both the initial amount of annual accumulation and the vertical compression the layer has been subject to since deposition (Paterson and Waddington, 1984). In this process, the ice layers are stretched horizontally until they are advected by the ice motion into an ablation zone (Rapp, 2012). The Chongce Core 2 was drilled on a flat platform with an area of over $160 \mathrm{~km}^{2}$ redistribution of snow. In addition, temporal changes in basal topography are likely minimal due to Holocene origin of the Chongce Core 2 (Hou et al., 2018; Licciulli et al., 2020). Therefore, here we estimated the vertical strain rate and accumulation rate of the Chongce Core 2 using a simple twoparameter steady state flow model (Bolzan, 1985):

$$
T_{(z)}=\frac{H}{b p}\left[\left(1-\frac{z}{H}\right)^{-p}-1\right]
$$

The model has two degrees of freedom, the net annual accumulation rate $b$ and the thinning parameter $p$, both of which are assumed to be constant over time. $H$ is the glacier thickness (m w.e.). $z$ is the depth (m w.e.), and $T_{(z)}$ is the corresponding age at $z$. For the Chongce Core 2 (drilled to bedrock), $H$ is 112.243 $\mathrm{m}$ water equivalent ( $\mathrm{m}$ w.e.), calculated as the product of the ice core length and its density. In order to not overweigh the data from the deepest horizons, the model is fitted using the logarithms of the age values (Uglietti et al., 2016). Using the established ${ }^{14} \mathrm{C}$ ages and the ages of other reference layers, we can fit the model by a nonlinear least squares approach. The set of known $z$ and $T_{(z)}$ are summarized in Table S1. The derived thinning parameter is 0.008 (dimensionless), and average annual accumulation of the entire ice core ( $\sim 9 \mathrm{ka}$ to present) is $103 \pm 34 \mathrm{~mm}$ w.e. (Fig. 2). This accumulation rate is in relative 
230 agreement with the average annual accumulation which was observed in the uppermost 50 annual layers ( $140 \mathrm{~mm}$ w.e./year) where the thinning effect is negligible (Hou et al., 2018). In addition, the modeled age at the depth of the oldest ${ }^{14} \mathrm{C}$ sample is $5.2 \pm_{1.4}^{1.9}$ ka B.P., similar to the actual ${ }^{14} \mathrm{C}$ age of $6.3 \pm 0.2 \mathrm{ka}$ B.P. given the uncertainty range. Therefore, the assumption of constant accumulation $(b)$ and a constant thinning parameter $(p)$ over time/with depth is reasonable.

\subsection{Accumulation rates of the past four time windows}

With the derived thinning parameter and average annual accumulation of the Holocene, we calculated the initial annual layer thickness ( $\mathrm{mm}$ w.e.) for the average accumulation rate at various depths for the Top Section, Section I, II, and III using a simple flow model for the decrease of the annual layer thickness with depth (Bolzan, 1985; Uglietti et al., 2016):

$$
L_{(z)}=b\left(1-\frac{\mathrm{z}}{H}\right)^{1+p}
$$

where $L_{(Z)}$ is the modeled annual layer thickness (mm w.e.) for the average accumulation rate $(b)$ at the depth of $z$ given the thinning parameter of $p$. The modeled annual layer thickness ranges 95.27-102.94 mm w.e. for the Top Section (corresponding to 1951-2012 A.D.), 47.01-47.30 mm w.e. for Section I (corresponding to $781-789$ a B.P.), 20.73-20.76 mm w.e. for section II (corresponding to 1682-1697 a B.P.), and 9.49-9.73 $\mathrm{mm}$ w.e. for section III (corresponding to 2511-2541 a B.P.). The initial accumulation (mm w.e.) for each annual layer can be derived through multiplying the ratio of the observed to modeled annual layer thickness ( $\mathrm{mm}$ w.e.) by the average annual accumulation rate (103 $\mathrm{mm}$ w.e.)(Hou et al., 2018; Roberts et al., 2015; Winstrup et al., 2012). The observed layer thickness is established in section 3.1. The results (Fig. 3) show that the mean annual accumulation was $102.10 \pm$ $33.28 \mathrm{~mm}$ w.e. at $\sim 2.5 \mathrm{ka}$ B.P., which is comparable to the Holocene mean value. It was $76.45 \pm 14.52$ mm w.e. at $\sim 1.7 \mathrm{ka}$ B.P. and $84.26 \pm 29.85 \mathrm{~mm}$ w.e. at $\sim 0.8 \mathrm{ka}$ B.P., about $25 \%$ and $18 \%$ lower than the Holocene mean respectively. Annual accumulation was $146.38 \pm 50.45 \mathrm{~mm}$ w.e. during 1953-2012 A.D., $\sim 42 \%$ higher than the Holocene mean.

\section{Discussion}

Alpine glaciers over the TP extend high into the middle troposphere, yielding ice cores that provide continuous annual accumulation records representative of a large area (Duan et al., 2015; Yao et al., 
2008). However, not all snowfall can be securely stored in high-elevation glaciers, due to wind scouring, snow drifting, and sublimation (Hardy et al., 2003). Therefore, ice core accumulation reconstructed in this paper is not a direct measurement of precipitation but rather a quantitative proxy of net precipitation in the western Kunlun Mountains. In Fig. 3, the reconstructed average annual accumulation of four time windows was compared with other reconstructed and modeled precipitation series for the TP to evaluate the reliability of our method of reconstruction. Thompson et al. (2006) reconstructed a snow accumulation record for the last millennium from an ice core retrieved at the Guliya ice cap $(\sim 30 \mathrm{~km}$ from the Chongce drilling site). Their reconstruction shows that snow accumulation rate for 1950-1989 A.D. (32.18 cm ice/year) is $62 \%$ higher than that for $1160-1169$ A.D. (19.79 $\mathrm{cm}$ ice/year) (Fig. 3b). This is largely consistent with the Chongce reconstruction, which shows a $65 \%$ increase in the mean annual accumulation between 1160-1172 A.D (84.28 mm w.e.) and 1953-1989 A.D (139.03 mm w.e.). Yang et al. (2014) reconstructed annual precipitation over the past 3500 years using subfossil, archaeological, and living juniper tree samples from the northeastern TP (Fig. 3c). Their reconstruction shows that the last 50 years is a very wet period relative to the past 3500 years, consistent with our reconstruction. In addition, both records show similar dry intervals in $\sim 0.8$ ka B.P. and $\sim 1.7$ ka B.P. and a moderately wet interval at $\sim 2.5$ ka B.P. (Fig. 3). Our reconstruction is also in agreement with the TraCE-21 ka model results (extracted for the study region of $34-36^{\circ} \mathrm{N}, 80-82^{\circ} \mathrm{E}$ ), which simulate continuous climate evolution over the last 21,000 years (Collins et al., 2006) (Fig. 3d). These results suggest that the method proposed in this study produces reliable results and has the potential to reconstruct high-resolution continuous precipitation time series.

Compared with the previous precipitation records based on paleoclimate proxies such as tree-ring width, pollen abundance index, ice core chemistry, and stalagmites, the method proposed in this paper has the significant advantage in quantifying annually-resolved precipitation of past millennia. Previous quantitative precipitation reconstructions assume a stationary linear relationship between proxy data and actual precipitation over time (Tozer et al., 2016; Yang et al., 2014), which is difficult to establish over long periods. In comparison, net accumulation rates in ice cores provides more direct and quantitative data for past precipitation. The establishment of a reliable annual accumulation record is determined only by two factors: (i) identification of the annual layers and (ii) the ice core thinning parameters. Therefore, comparison of the average annual accumulation of each section with the Holocene average was not influenced by the error of ice core chronology caused by two-parameter flow model. Moreover, ice core 
accumulation records could be used to quantify annual precipitation over Antarctica and the Greenland ice cap, where no other precipitation proxies exist.

The reliability of this method can be further improved with the existence of absolute chronological markers (e.g., volcanic events and archaeological archives). If such markers exist in an ice core, a local average annual layer thickness $(b)$ can be calculated between two adjacent markers by dividing the length of ice by the number of annual layers between them. The average net annual accumulation can then be determined from ratio of the average net annual layer thickness ( $\mathrm{mm}$ w.e.) to the flow-modeled thickness (mm w.e.) multiplied by the average annual accumulation of the Holocene. This provides an additional way to verify the reconstructed accumulation rates. As a result, we can improve the reliability of our method by comparing three different reconstructions (i.e., the Holocene net mean accumulation derived from the two-parameter model, average net annual accumulation between adjacent absolute chronological markers, and average net annual accumulation of different time windows based on annual layer identification). In addition, we will perform more direct observations (e.g., surface and bedrock topography and borehole inclination angles) on the Chongce ice cap in the future and use them to constrain a state-of-the-art 3-D ice core model (Licciulli et al., 2020). This could further improve our estimates of accumulation rate and the thinning parameter.

\section{Conclusions}

In this paper, we presented a new method to quantify annual accumulation from ice cores for past millennia, using as an example an ice core drilled at the Chongce ice cap in the northwestern TP. We used the LA-ICP-MS technology to develop continuous ultra-high-resolution records of chemical constituents ( $\mathrm{Al}, \mathrm{Ca}, \mathrm{Fe}, \mathrm{Na}, \mathrm{Mg}, \mathrm{Cu}$, and $\mathrm{Pb}$ ) in three sections of the Chongce ice core (corresponding to 781-789 a B.P., 1682-1697 a B.P., and 2511-2541 a B.P in age respectively). Based on the seasonality shown in these trace element records ( $\mathrm{Al}, \mathrm{Ca}, \mathrm{Fe}$, and $\mathrm{Mg}$ ), we identified annual layers in each section. In addition, annual layers of the Top Section of Chongce ice core (1953-2012 A.D. in age) were identified based on seasonal cycles of $\delta^{18} \mathrm{O}$ values. The thickness of these annual layers was subsequently corrected using a two-parameter flow model to establish initial net accumulation for these sections. The results show that the average annual accumulation was $102 \mathrm{~mm}$ around $2.5 \mathrm{ka}$ B.P., which is comparable to the Holocene average. The average accumulation was $76 \mathrm{~mm}$ at $1.7 \mathrm{ka} \mathrm{B.P.} \mathrm{and} 84 \mathrm{~mm}$ at $0.8 \mathrm{ka}$ B.P., about 
A.D., about $41 \%$ higher than the Holocene average. Our estimates are consistent with previous results from tree rings and the TraCE-21 ka transient model simulations. Therefore, the method has the potential to reconstruct continuous high resolution precipitation records covering millennia or even longer time periods.

\section{Acknowledgments}

Many thanks are due to many scientists, technicians, graduate students and porters, especially to Yongliang Zhang, Hao Xu, and Yaping Liu, for their great efforts working at high elevations, to Mariusz Potocki for his help in measuring chemical constituents of ice core samples, to Chiara Uglietti and Heinz Walter Gäggeler for help in measuring the ${ }^{14} \mathrm{C}$ samples, and to Guocai Zhu for providing the groundpenetrating radar results. In China, this work was supported by the National Natural Science Foundation of China (91837102, 41830644, and 42001050). In USA, the Climate Change Institute's W.M. Keck Laser Ice Facility and their ICP-MS laboratory at the University of Maine gratefully acknowledges support for this facility from the W. M. Keck Foundation and US National Science Foundation (PLR042883, PLR-1203640, and PLR-1417476). The data for the work in this paper can be downloaded from the Zenodo website (available from: http://doi.org/10.5281/zenodo.4387022).

\section{References}

An, W., Hou, S., Zhang, W., Wu, S., Xu, H., Pang, H., Wang, Y., and Liu, Y.. Possible recent warming hiatus on the northwestern Tibetan Plateau derived from ice core records, Sci. Rep., 6, 32813, https://doi.org/10.1038/srep32813, 2016.

Alley, R. B., Meese, D. A., Shuman, C. A., Gow, A. J., Taylor, K. C., Grootes, P. M., White, J. W. C., Ram, M., Waddington, E. D., Mayewski, P. A., and Zielinski, G. A.: Abrupt increase in Greenland snow accumulation at the end of the Younger Dryas event, Nature, 362, 527-529, https://doi.org/10.1038/362527a0, 1993.

Bohleber, P., Erhardt, T., Spaulding, N., Hoffmann, H., Fischer, H., and Mayewski, P.: Temperature and mineral dust variability recorded in two low-accumulation Alpine ice cores over the last millennium,

Clim. Past, 14, 21-37, https://doi.org/10.5194/cp-14-21-2018, 2018. 
Bolzan, J. F.: Ice flow at the Dome C ice divide based on a deep temperature profile, J. Geophys. Res., 90(D5), 8111-8124, https://doi.org/10.1029/JD090iD05p08111, 1985.

Bronk Ramsey, C., and Lee, S.: Recent and planned developments of the program Oxcal, Radiocarbon, 55, 720-730. https://doi.org/10.1017/S0033822200057878, 2013.

Cai, Y., Zhang, H., Cheng, H., An, Z., Edwards, R. L., Wang, X., Tan, L., Liang, F., Wang, J., and Kelly, M.: The Holocene Indian monsoon variability over the southern Tibetan Plateau and its teleconnections, Earth Planet. Sci. Lett., 335-336, 135-144, https://doi.org/10.1016/j.eps1.2012.04.035, 2012.

Christiansen, B., and Ljungqvist, F. C.: Challenges and perspectives for large-scale temperature for largescale temperature reconstructions of the past two millennia, Rev. Geophys., 55, 40-96, https://doi.org/10.1002/2016RG000521, 2017.

Clifford, H. M., Spaulding, N. E., Kurbatov, A. V., More, A., Korotkikh, E. V., Sneed, S. B., Handley, M., Maasch, K. A., Loveluck, C. P., Chaplin, J., McCormick, M., and Mayewski, P. A.: A 2000 year Saharan dust event proxy record from an ice core in the European Alps, J. Geophys. Res. Atmos., 124, 12882-12900, https://doi.org/10.1029/2019JD030725, 2019.

Collins, W. D., Bitz, C. M., Blackmon, M. L., Bonan, G. B., Bretherton, C. S., Carton, J. A., Chang, P., Doney, S. C., Hack, J. J., Henderson, T. B., Kiehl, J. T., Large, W. G., McKenna, D. S., Santer, B. D., and Smith, R. D.: The Community Climate System Model Version 3 (CCSM3), J. Climate, 19(11), 2122-2143, https://doi.org/10.1175/JCLI3761.1, 2006.

Dahl-Jensen, D., Johnsen, S. J., Hammer, C. U., Clausen, H. B., and Jouzel, J.: Past Accumulation rates derived from observed annual layers in the GRIP ice core from Summit, Central Greenland, in: Ice in the Climate System, edited by: Peltier, W. R., NATO ASI Series, 12, 517-532, https://doi.org/10.1007/978-3-642-85016-5_29, 1993.

Duan, K., Xu, B., and Wu, G.: Snow accumulation variability at altitude of $7010 \mathrm{~m}$ a.s.l. in Muztag Ata Mountain in Pamir Plateau during 1958-2002. J. Hydrol., 531, 912-918, https://doi.org/10.1016/j.jhydrol.2015.10.013, 2015.

Haines, S. A., Mayewski, P. A., Kurbatov, A. V., Maasch, K. A., Sneed, S. B., and Spaulding, N.: Ultrahigh resolution snapshots of three multi-decadal periods in Antarctic ice core, J. Glaciol., 62(231), 31-36, https://doi.org/10.1017/jog.2016.5, 2016. 
Hardy, D. R., Vuille, M., and Bradley, R. S.: Variability of snow accumulation and isotopic composition on Nevado Sajama, Bolivia. J. Geophys. Res, 108(D22), https://doi.org/10.1029/2003JD003623, 2003.

Henderson, K., Laube, A., Gäggeler, H. W., Olivier, S., Papina, T., and Schwikowski, M.: Temporal variations of accumulation and temperature during the past two centuries from Belukha ice core, Siberian Altai, J. Geophys. Res., 111, D03104, https://doi.org/10.1029/2005JD005819, 2006.

Hou, S., Qin, D., Yao, T., Zhang, D., and Chen, T.: Recent change of the ice core accumulation rates on the Qinghai-Tibetan Plateau, Chinese Sci. Bull., 47(20), 1746-1749, https://doi.org/10.1360/02tb9382, 2002.

Hou, S., Jenk, T. M., Zhang, W., Wang, C., Wu, S., Wang, Y., Pang, H., and Schwikowski, M.: Age ranges of the Tibetan ice cores with emphasis on the Chongce ice cores, western Kunlun Mountains, The Cryosphere, 12, 2341-2348, http://doi.org/10.5194/tc-12-2341-2018, 2018.

Kaspari, S., Hooke, R. L., Mayewski, P. A., Kang, S., Hou, S., and Qin, D.: Snow accumulation rate on Qomolangma (Mount Everest), Himalaya: synchroneity with sites across the Tibetan Plateau on 50100 year timescale, J. Glaciol., 54(185), 343-352, https://doi.org/10.3189/002214308784886126, 2008.

Kidd, C., and Huffman, G.: Global precipitation measurement, Meteorol. Appl., 18, 334-353, https://doi.org/10.1002/met.284, 2011.

Liu, Z., Otto-Bliesner, B. L., He, F., Brady, E. C., Tomas, R., Clark, P. U., Carlson, A. E., Lynch-Stieglitz, J., Curry, W., Brook, E., Erickson, D., Jacob, R., Kutzbach, J., and Cheng, J.: Transient Simulation of Last Deglaciation with a New Mechanism for Bølling-Allerød Warming, Science, 325(5938), 310-314, https://doi.org/10.1126/science.1171041, 2009.

Licciulli, C., Bohleber, P., Lier, J., Gagliardini, O., Hoelzle, M., and Eisen, O.: A full Stokes ice-flow model to assist the interpretation of millennial-scale ice cores at the high-Alpine drilling site Colle Gnifetti, Swiss/Italian Alps, J. Glaciol., 66(255), 35-48, https://doi.org/10.1017/jog.2019.82, 2020.

Massam, A., Sneed, S. B., Lee, G. P., Tuckwell, R. R., Mulvaney, R., Mayewski, P. A., and Whitehouse, P. L.: A comparison of annual layer thickness model estimates with observational measurements using the Berkner Island ice core, Antarctica, Antarct. Sci., 29(4), 382-393, https://doi.org/10.1017/S0954102017000025, 2017. 

and variability over the Tibetan Plateau as resolved by the High Asia Reanalysis, J. Climate, 27(5), 1910-1927, https://doi.org/10.1175/JCLI-D-13-00282.1, 2014.

More, A. F., Spaulding, N. E., Bohleber, P., Handley, M. J., Hoffmann, H., Korotkikh, E. V., Kurbatov, A. V., Loveluck, C. P., Sneed, S. B., McCormick, M., and Mayewski, P. A.: Next generation ice core technology reveals true minimum natural levels of lead $(\mathrm{Pb})$ in the atmosphere: Insights from the black death, GeoHealth, 1, 211-219, https://doi.org/10.1002/2017GH000064, 2017.

Nye, J. F.: Correction Factor for Accumulation Measured by the Thickness of the Annual Layers in an Ice Sheet, J. Glaciol., 4, 785-788, https://doi.org/10.3189/S0022143000028367, 1963.

Paterson, W. S. B., and Waddington, E. D.: Past precipitation rates derived from ice core measurements:

Methods and data analysis, Rev. Geophys., 22(2), 123-130, https://doi.org/10.1029/RG022i002p00123, 1984.

Parrenin, F., Rémy, F., Ritz, C., Siegert, M. J., and Jouzel, J.: New modeling of the Vostok ice flow line and implication for the glaciological chronology of the Vostok ice core, J. Geophys. Res., 109, D20202, https://doi.org/10.1029/2004JD004561, 2004.

Rapp, D.: Glacials and Interglacials: Measurement, Interpretation and Models, Springer-Verlag, Berlin, https://doi.org/10.1007/9783-642-30029-5-11, 2012.

Reimer, P. J., Bard, E., Bayliss, A., Beck, J. W., Blackwell, P. G., Ramsey, C. B., Buck, C. E., Cheng, H., Lawrence Edwards, R., Friedrich, M., Grootes, P. M., Guilderson, T. P., Haflidason, H., Irka Hajdas, I., Hatté, C., Heaton, T. J., Hoffmann, D. L., Hogg, A. G., Hughen, K. A., Kaiser, K. F., Kromer, B., Manning, S. W., Niu, M., Reimer, R. W., Richards, D. A., Scott, E. M., Southon, J. R., Staff, R. A., Turney, C. S. M., and van der Plicht, J.: IntCal13 and marine13 radiocarbon age calibration curve $0-50,000$ years cal BP, Radiocarbon, 55, 1869-1887, https://doi.org/10.2458/azu_js_rc.55.16947, 2013.

Roberts, J., Plummer, C., Vance, T., van Ommen, T., Moy, A., Poynter, S., Treverrow, A., Curran, M., and George, S.: A 2000-year annual record of snow accumulation rates for Law Dome, East Antarctica, Clim. Past, 11, 697-707, https://doi.org/10.5194/cp-11-697-2015, 2015.

Shi, Y. (Ed.): Concise Glacier Inventory of China, Shanghai Popular Science Press, China, 2008.

Sigl, M., Jenk, T. M., Kellerhals, T., Szidat, S., Gäggeler, H. W., Wacker, L., Synal, H.-A., Boutron, C., Barbante, C., Gabrieli, J., and Schwikowski, M.: Instruments and methods towards radiocarbon 
dating of ice cores, J. Glaciol., 55(194), 985-996, https://doi.org/10.3189/002214309790794922, 2009.

Sneed, S. B., Mayewski, P. A., Sayre, W. G., Handley, M. J., Kurbatov, A. V., Taylor, K. C., Bohleber, P., Wagenbach, D., Erhardt, T., and Spaulding, N. E.: New LA-ICP-MS cryocell and calibration technique for sub-millimeter analysis of ice cores, J. Glaciol., 61(226), 233- 242, https://doi.org/10.3189/2015JoG14J139, 2015.

Spaulding, N. E., Sneed, S. B., Handley, M. J., Bohleber, P., Kurbatov, A. V., Pearce, N. J., Erhardt, T., and Mayewski, P. A.: A new multielement method for LA-ICP-MS data acquisition from glacier ice cores, Environ. Sci. Technol., 51(22), 13282-13287, https://doi.org/10.1021/acs.est.7b03950, 2017.

Sun, Q., Miao, C., Duan, Q., Ashouri, H., Sorooshian, S., and Hsu, K.-L.: A review of global precipitation data sets: Data sources, estimation, and intercomparisons, Rev. Geophys., 56, 79-107, https://doi.org/10.1002/2017RG000574, 2018.

Tang, Y., Pang, H., Zhang, W., Li, Y., Wu, S., and Hou, S.: Effects of changes in moisture source and the upstream rainout on stable isotopes in precipitation - A case study in Nanjing, eastern China, Hydrol. Earth Syst. Sci., 19(10), 4293-4306. https://doi.org/10.5194/hess-19-4293-2015, 2015.

Thompson, L., Mosley-Thompson, E., Brecher, H., Davis, M., León, B., Les, D., Lin, P.-N., Mashiotta, T., and Mountain, K.:Abrupt tropical climate change: Past and present, P. Natl. Acad. Sci. USA, 103(28), 10536-10543, https://doi.org/10.1073/pnas.0603900103, 2006.

Thompson, L. G., Yao, T., Davis, M. E., Mosley-Thompson, E., Wu, G., Porter, S. E., Xu, B., Lin, P. N., Wang, N., Beaudon, E., Duan, K., Sierra-Hernández, M. R., and Kenny, D. V.: Ice core records of climate variability on the Third Pole with emphasis on the Guliya ice cap, western Kunlun Mountains, Quaternary Sci. Rev., 188, 1-14, https://doi.org/10.1016/j.quascirev.2018.03.003, 2018.

Tozer, C. R., Vance, T. R., Roberts, J. L., Kiem, A. S., Curran, M. A. J., and Moy, A. D.: An ice core derived 1013-year catchment-scale annual rainfall reconstruction in subtropical eastern Australia, Hydrol. Earth Syst. Sci., 20, 1703-1717, https://doi.org/10.5194/hess-20-1703-2016, 2016.

Uglietti, C., Zapf, A., Jenk, T. M., Sigl, M., Szidat, S., Salazar, G., and Schwikowski, M.: Radiocarbon dating of glacier ice: overview, optimization, validation, and potential, The Cryosphere, 10, 30913105, https://doi.org/10.5194/tc-10-3091-2016, 2016. 
Winstrup, W., Svensson, A. M., Rasmussen, S. O., Winther, O., Steig, E. J., and Axelrod, A. E.: An automated approach for annual layer counting in ice cores, Clim. Past, 8, 1881-1895, https://doi.org/10.5194/cp-8-1881-2012, 2012.

Winstrup, M., Vallelonga, P., Kjaer, H. A., Fudge, T. J., Lee, J. E., Riis, M. H., Edwards, R., Bertler, N. A. N., Blunier, T., Brook, E. J., Buizert, C., Ciobanu, G., Conway, H., Dahl-Jensen, D., Ellis, A., Emanuelsson, B. D., Hindmarsh, R. C. A., Keller, E. D., Kurbatov, A. V., Mayewski, P. A., Neff, P. D., Pyne, R. L., Simonsen, M. F., Svensson, A., Tuohy, A., Waddington, E. D., and Wheatley, S.: A 2700-year annual timescale and accumulation history for an ice core from Roosevelt Island, West Antarctica, Clim. Past, 15(2), 751- 779, https://doi.org/10.5194/cp-15-751-2019, 2019.

Xu, T., Zhu, Lü, X., Ma, Q., Wang, J., Ju, J., and Huang, L.: Mid- to late-Holocene paleoenvironmental changes and glacier fluctuations reconstructed from the sediments of proglacial lake Buruo Co, northern Tibetan Plateau, Palaeogeogr. Palaeocl., 517, 74-85, https://doi.org/10.1016/j.palaeo.2018.12.023, 2019.

Yang, B., Qin, C., Wang, J., He, M., Melvin, T. M., Osborn, T. J., and Briffa, K. R. (2014), A 3500-year tree-ring record of annual precipitation on the northeastern Tibetan Plateau, P. Natl. Acad. Sci. USA, 111(8), 2903-2908, https://doi.org/10.1073/pnas.1319238111, 2014. ice cores on the central Tibetan Plateau, Clim. Past, 4, 175-180, https://doi.org/10.5194/cp-4-1752008,2008 .

Zhang, Y., Kang, S., Zhang, Q., Grigholm, B., Kaspari, S., You, Q., Qin, D., Mayewski, P. A., Cong, Z., Huang, J., Sillanpää, M., Chen, F.: A 500 year atmospheric dust deposition retrieved from a Mt. Geladaindong ice core in the central Tibetan Plateau, Atmos. Res., 166, 1-9, https://doi.org/10.1016/j.atmosres.2015.06.007, 2015.

Zhang, Z., Hou, S., and Yi, S.: The first luminescence dating of Tibetan glacier basal sediment, The Cryosphere, 12, 163-168, https://doi.org/10.5194/tc-12-163-2018, 2018. 

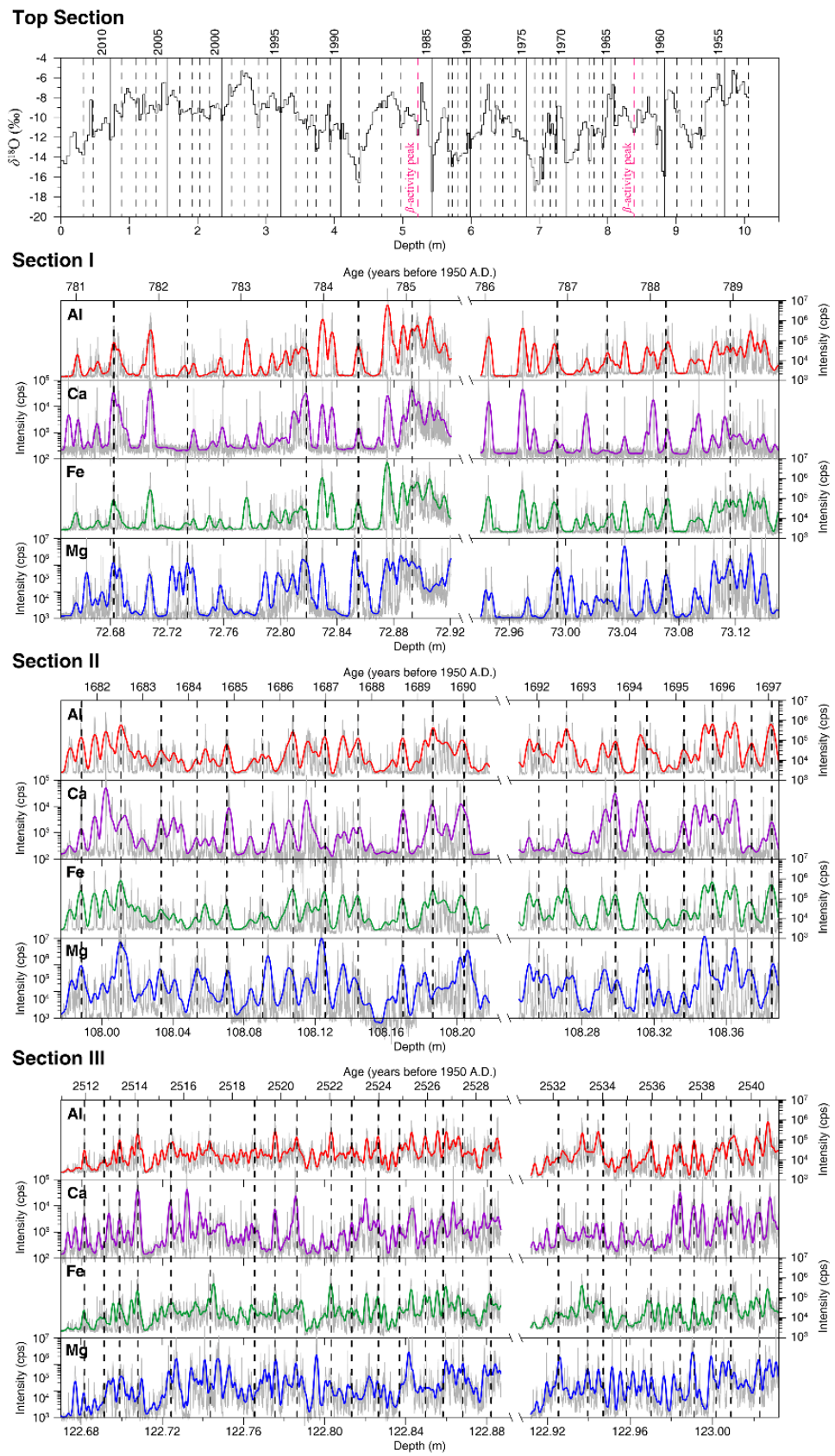

485 Figure 1. Annual layer counting for the Top Section, Section I, II, and III (top to bottom). The annual layers of the Top Section are identified based on the seasonality of $\delta^{18} \mathrm{O}$ and two $\beta$-activity peaks (An et al., 2016). The annual layers of Section I, II, and III are marked at the winter/spring peaks (black dotted lines) of $\mathrm{Al}, \mathrm{Ca}, \mathrm{Fe}$, and $\mathrm{Mg}$ 
concentrations. Thin grey lines indicate raw data, and thick colored lines represent 200-

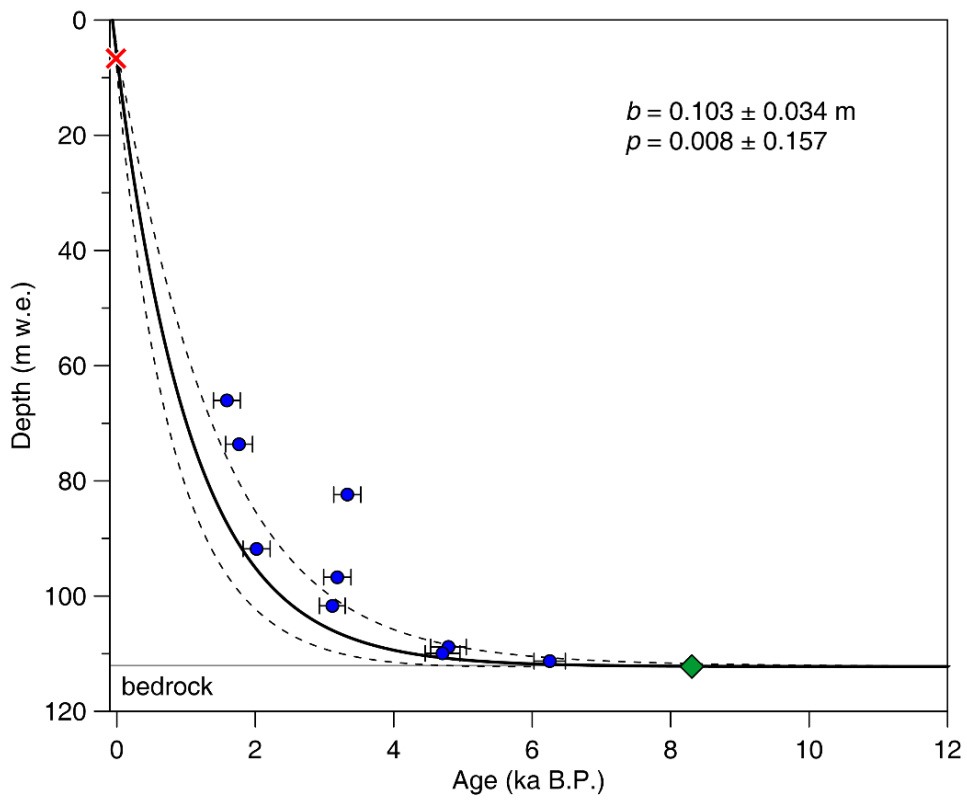

Figure 2. The depth-age relationship of the Chongce Core 2 based on the twoparameter model. The dashed lines represent the $1 \sigma$ confidence interval of the twoA.D., the blue dots the calibrated ${ }^{14} \mathrm{C}$ ages with $1 \sigma$ error bar, green diamond for bedrock age estimate from the Chongce Core 4 (Hou et al., 2018; Zhang et al., 2018). 

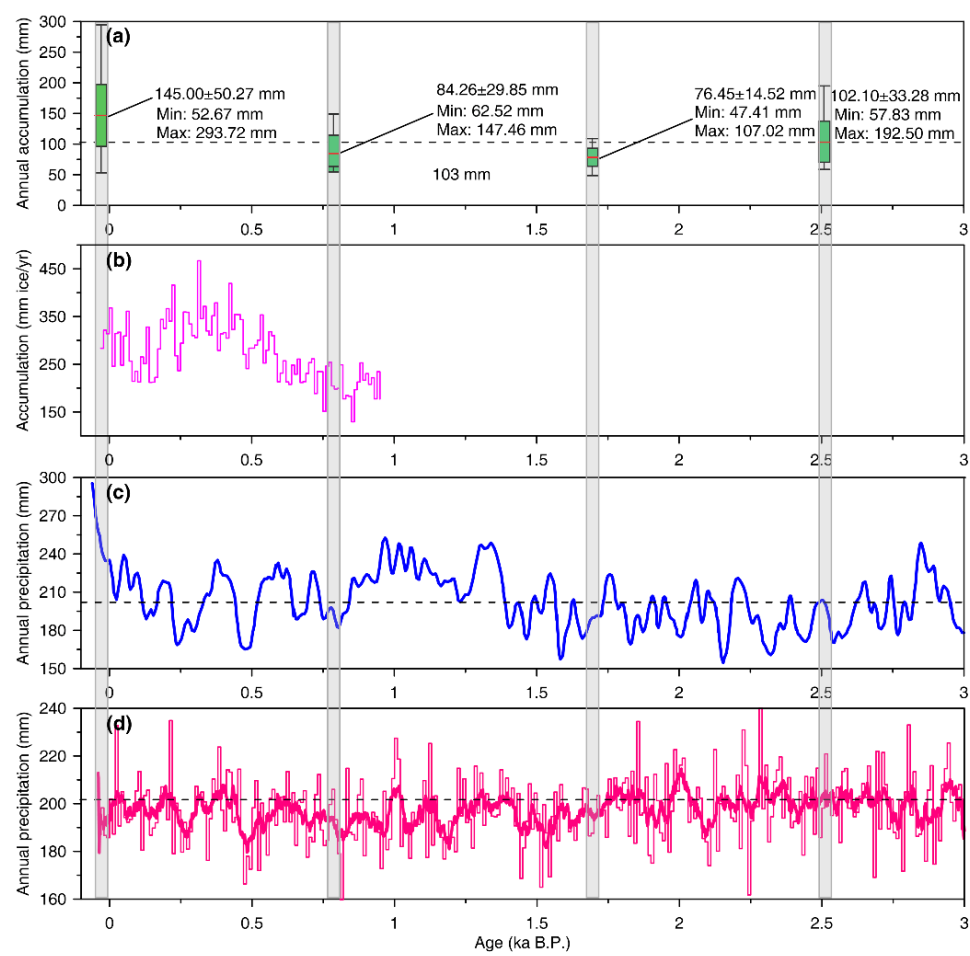

Figure 3. Our reconstructed annual accumulation for each of the four sections sampled (a) and its comparison with (b) snow accumulation reconstruction based on the Guliya ice core (Thompson et al., 2006), (c) precipitation reconstruction with 50-year smoothing in the northeastern TP (Yang et al., 2014), and (d) the TraCE-21 ka model results for the region $\left(34-36^{\circ} \mathrm{N}, 80-82^{\circ} \mathrm{E}\right)$ (Collins et al., 2006). The dotted lines in (a) and (d) represent the average annual accumulation over the Holocene. The dotted line in (c) represent average annual accumulation over the past $3.0 \mathrm{ka}$. The thin and thick red lines in (d) represent 10-year and 50-year moving average respectively. 